\title{
Analisis Penggunaan Aplikasi Pelaporan Dana Bantuan Operasional Sekolah (BOS)
}

\author{
Ishak \\ Magister Teknik Elektro Universitas Tanjungpura Pontianak. \\ Staf Pengajar SMK Negeri 2 Pontianak \\ e-mail : ishak.satar@gmail.com
}

\begin{abstract}
Dana BOS yang dikucurkan pemerintah ke sekolah harus dipertanggung jawabkan dalam bentuk laporan sesuai dengan format yang telah ditentukan. Namun sebagian besar sekolah masih melakukan pencatatan transaksi pembukuan dana BOS secara manual, sehingga kadang terjadi human error seperti kesalahan dalam penulisan data yang menyebabkan data menjadi tidak akurat dan relevan. Tujuan dari penelitian ini adalah membangun aplikasi sistem informasi pengelolaan Dana Bantuan Oprasional Sekolah (BOS) yang memudahkan pencatatan transaksi pembukuan pada Buku Kas Umum (BKU), Buku Pembantu Kas (BPK), Buku Pembantu Bank (BPB), Buku Pembantu Pajak (BPP) dan membantu Manajemen SMK Negeri 2 Pontianak dalam pelaporan penggunaan dana BOS. Aplikasi ini dirancang untuk digunakan oleh Bendahara BOS dalam melakukan pencatatan transaksi keuangan. Dengan mengunakan Aplikasi Pelaporan Dana BOS proses pekerjaan lebih menjadi singkat dari proses pekerjaan secara manual sehingga terjadi penghematan pemakaian kusumsi energy listrik. Pengujian aplikasi dilakukan dengan metode pengujian black box dan hasil pengujiannya telah berjalan sesuai dengan fungsinya yang diharapkan. Hasil akhir pada penelitian ini menghasilkan sebuah aplikasi yang mampu mengatasi masalah dalam pembukuan pada laporan BOS.
\end{abstract}

Keywords- BOS, Aplikasi pelaporan, $B K U, B P K, B P B, B P P$

\section{Pendahuluan}

Dana BOS harus dipertanggung jawabkan dalam bentuk laporan sesuai dengan format yang telah ditentukan. Namun sebagian besar sekolah termasuk SMK Negeri 2 Pontianak masih melakukan pencatatan transaksi pembukuan dana BOS secara manual, sehingga kadang terjadi human error seperti kesalahan dalam penulisan data yang menyebabkan data menjadi tidak akurat dan relevan.

Menanggapi adanya kendala tersebut, maka dibuatlah sebuah sistem informasi menggunakan web yang dapat memudahkan dan menyederhanakan pencatatan transaksi pembukuan untuk dapat mengatasi masalah tersebut. Dengan adanya sistem informasi ini diharapkan dapat menampilkan informasi yang relevan dan lengkap serta dapat menyiapkan database secara akurat.

\section{Teori Dasar}

Menurut Ardia Nuranto (2014), Penelitian terdahulu yang memaparkan "Sistem Informasi Pelaporan Dana BOS SD Negeri 006 Tanjung Pinang Timur". Implementasi yang dibangun melalui bahasa pemograman Visual Basic 6.0 dan Microsoft Access 2007 sebagai databasenya. Hasil dari penelitian ini berupa software aplikasi yang bisa digunakan untuk membuat RKAS dan BKU di SD Negeri 006 Tanjung Pinang Timur.

Menurut Rio Ridha Ariestyo (2013), Penelitian sebelumnya membahas "Sistem Informasi Pengelolaan Dana Bantuan Operasional Sekolah (BOS) di SMP Surabaya". Sistem informasi ini dapat membantu sekolah dalam proses penyusunan rencana anggaran pendapatan belanja sekolah (RAPBS) setiap tahun, dan penyusunan realisasi pelaporan penggunaan dana BOS setiap triwulannya dalam bentuk buku kas umun (BKU) sehingga memudahkan dinas pendidikan dalam pengecakan pelaporan dana bantuan operasional sekolah yang telah disalurkan ke sekolah.

Kedua peneliti sebelumnya merancang aplikasi untuk membuat Rencana Kerja dan Anggaran Sekolah (RKAS) / Rencana Anggaran Pendapatan Belanja Sekolah (RAPBS) dan Buku Kas Umum (BKU) pada tingkatan sekolah yang berbeda yaitu SD dan SMP.

A. Aplikasi Berbasis Web

Menurut Kadir (2006), menyatakan bahwa aplikasi berbasis web "Hanya menggunkan bahasa yang disebut HTML (Hyper Text Markup Languange) dan protokol yang digunakan dinamakan HTTP (Hyper Text Transfer Protocol)"

Berdasarkan uraian diatas dapat disimpulkan bahwa aplikasi berbasis web adalah sebuah aplikasi yang merupakan suatu perangkat lunak computer yang dikodekan dalam bahasa pemograman yang mendukung perangkat lunak berbasis web seperti HTML, JavaScrip, Ruby, Python, PHP dan bahasa pemograman lainnya, yang diakses melalui jaringan komputer.

B. Hypertext Preprocessor (PHP)

Menurut Sidik (2014), menyatakan bahwa PHP "Bahasa pemograman berbasiskan skrip-skrip yang membuat dokumen HTML secara on the fly yang dieksekusi di server web, dokumen HTML yang dihasilkan dari suatu aplikasi bukan dokumen HTML yang dibuat dengan menggunakan editor teks atau editor HTML".

Berdasarkan uraian diatas dapat disimpulkan bahwa PHP adalah bahasa pemograman skrip server-side yang didesain 
untuk pengembangan web dan membuat dokumen HTML kemudian dieksekusi server web dan hasilnya akan terkirim ke browser dengan format HTML.

C. MySQL

Menurut Sidik (2014), menyatakan bahwa MySQL "Software database yang termasuk paling popular dilingkungan linux". Salah satu jenis database server yang sangat terkenal dan banyak digunakan untuk membangun aplikasi web yang menggunakan database sebagai sumber dan pengolahan datanya (Arief, 2011)

Berdasarkan uraian diatas dapat disimpulkan bahwa MySQL adalah database server yang bersifat open source yang dapat digunakan untuk membuat dan mengelola database beserta isinya. Performan quary dari databasenya yang saat itu bisa dikatakan paling cepat dan jarang bermasalah.

D. Javascipt

Menurut Sigit (2011), "JavaScript merupakan bahasa scripting yang bekerja di sisi Clien/Browser sehingga webset bisa lebih interaktif'.

Menurut Kustiyahningsih dan Anamisa (2011), "JavaScript adalah bahasa pemograman untuk memberikan kemampuan tambahan terhadap bahasa HTML dengan mengizinkan pengeksekusian perintahperintah disisi pengguna, artinya disisi browser dan bukan disisi web server".

Berdasrkan uraian diatas dapat disimpulkan bahwa JavaSript merupakan bahasa pemograman yang pemrosesannya dilakukan oleh client yang memberikan kemampuan terhadap bahasa HTML

E. Black Box

Menurut Pressman (2002), menyatakan bahwa pengujian black box, "berfokus pada persyaratan fungsional perangkat lunak. Pengujian black box memungkinkan perekayasaan perangkat lunak mendapatkan serangkian kondisi input yang sepenuhnya menggunkan persyaratan fungsional untuk suatu program"

\section{Buku Kas Umum (BKU), Buku Pembantu Kas (BPK), Buku Pembantu Bank (BPB) dan Buku Pembantu Pajak (BPP)}

\section{A. Buku Kas Umum}

Buku Kas Umum merupakan buku kas besar untuk seluruh transaksi kas, baik transaksi kas tunai maupun transaksi kas melalui Bank. Secara umum buku ini mengambarkan dua kolom utama yakni kolom penerimaan dan kolom pengeluaran. Kolom penerimaan menjelaskan dana BOS SMK yang masuk, sementara kolom pengeluaran menjelaskan pembelian barang dan jasa yang menggunkan dana BOS SMK atau mutasi antar rekening bank dan kas kecil. Buku Kas Umum harus diisi tiap transaksi. Transaksi yang dicatat dalam kas umum kemudian juga dicatat buku pembantu, yakni Buku Pembantu Kas, Buku Pembantu Bank dan Buku Pembantu Pajak.

Saldo akhir buku Kas Umum harus sama dengan penjumlahan dari seluruh saldo akhir Buku Pembantu Kas, Buku Pembantu Bank dan Buku Pembantu Pajak.

A. Buku Pembantu Kas

Buku Pembantu Kas merupakan buku besar pembantu untuk mencatat setiap transaksi kas secara tunai dan ditandatangi oleh Bendahara BOS dan Kepala Sekolah setiap akhir bulannya.

B. Buku Pembantu Bank

Buku Pembantu Bank merupakan buku besar pembantu untuk mencatat setiap transaksi yang dilakukan melalui Bank (baik cek, giro maupun transfer). Buku Pembantu Bank dibuat setiap setiap rekening Bank yang digunakan dalam pengelolaan dana BOS

C. Buku Pembantu Pajak

Pembantu Pajak merupakan buku besar untuk mencatat semua transaksi pemungutan pajak oleh Sekolah sebagai Wajib Pajak (WP).

\section{Konsep Penelitian}

Konsep merupakan suatu uraian dan visualisasi tentang hubungan atau kaitan antara konsep-konsep atau variable yang akan diamati atau diukur melalui penelitian yang akan dilakukan (Notoatmojo,2012).

Berdasarkan konsep maka tujuan penelitian yaitu untuk menganalisis penggunaan aplikasi sistem informasi pengelolaan Dana Bantuan Oprasional Sekolah (BOS) yang memudahkan pencatatan transaksi pembukuan pada Buku Kas Umum, Buku Pembantu Kas, Buku Pembantu Bank, Buku Pembantu Pajak dan membantu manajemen SMK Negeri 2 Pontianak dalam pelaporan penggunaan dana BOS setiap triwulan ke Diknasbud Provinsi Kalimantan Barat. Adapun tahap penelitian dapat dilihat pada Gambar 1

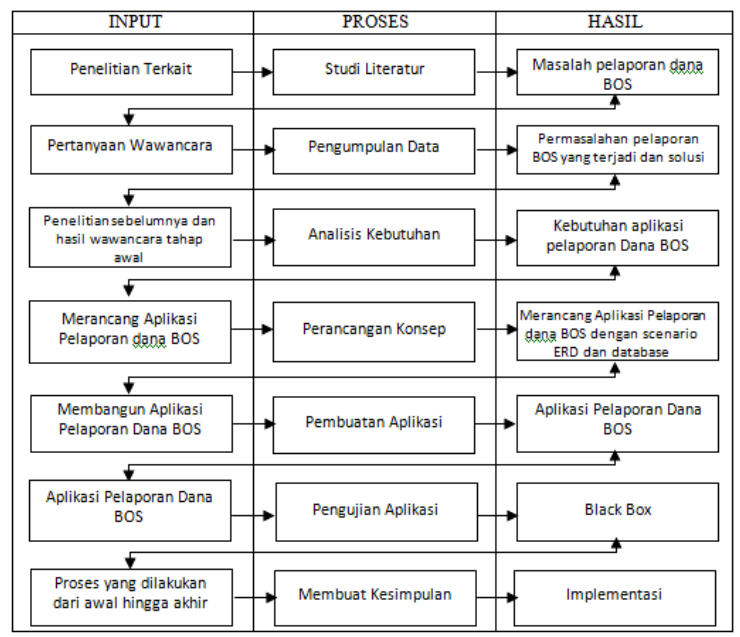

Gambar 1 Diagram Alir Penelitian

Penelitian ini dilakukan dengan analisis kebutuhan data dan informasi yang dibutuhkan untuk merancang dan membangun aplikasi pelaporan dana BOS berbasis Web.

\section{Perancangan Konsep}

Perancangan konsep dibuat untuk membuat konsep dan merancang aplikasi yang akan dibangun. Proses ini dilakukan dengan skenario alur aplikasi, Entity Relationship Diagram (ERD) dan Spesifikasi Tabel.

2. Pengujian Aplikasi

Pengujian aplikasi bertujuan untuk mengetahui apakah aplikasi telah memenuhi kebutuhan pengguna. Pengujian aplikasi dilakukan dengan black box.

3. Membuat Kesimpulan 
Kesimpulan akan didapat setelah aplikasi sudah dibangun dan dilakukan pengujian aplikasi untuk mengetahui tingkat keberhasilan sebuah aplikasi yang dibangun.

\subsection{Analisis Kebutuhan}

A. Kebutuhan User

Kebutuhan user merupakan tahapan untuk menentukan kebutuhan apa saja yang diperlukan oleh pengguna. Kebutuhan user tersebut dapat dilihat pada Tabel.

\begin{tabular}{|l|l|l|}
\multicolumn{3}{|c|}{ Tabel 1 Analisa Kebutuhan User } \\
\hline No & \multicolumn{1}{|c|}{ User } & \multicolumn{1}{|c|}{ Peran } \\
\hline 1. & Admin & User yang mengelola apalikasi \\
& Bendahara) & Pelaporan Dana BOS \\
& & \\
\hline
\end{tabular}

B. Kebutuhan Antarmuka

Adapun kebutuhan antarmuka yang diperluan yaitu :

1. Aplikasi mampu membaca data

2. kunci pada saat proses pencarian, pemasukan data dan penghapusan data

3. Aplikasi mampu menyimpan data yang dimasukkan oleh admin ke dalam strorage

4. Aplikasi mampu memperbaharui semua data yang disimpan dalam strorage.

D. Proses Pengolahan Laporan Dana BOS

Berikut ini akan dijelaskan secara singkat bagaimana proses pengolahan data pelaporan Dana BOS yang dilakukan pada SMK Negeri 2 Pontianak dapat dilihat pada Gambar 2

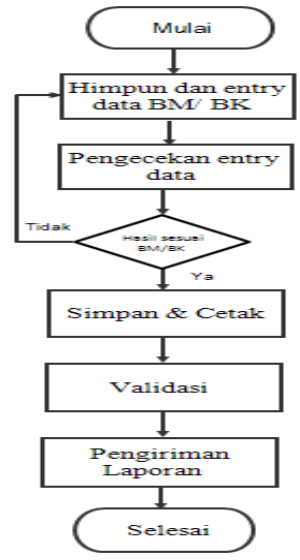

Gambar 2 Bagan Alir Pelaporan Dana BOS SMK Negeri 2 Pontianak

\subsection{Spesifikasi Perangkat}

Aplikasi yang dibuat menggunakan beberapa perangkat lunak dan perangkat keras agar dapat berjalan secara optimal. Spesifikasi perangkat-perangkat tersebut yaitu :
A. Analisis Kebutuhan Perangkat Lunak ini adalah :
a. Sistem Operasi Windows 10 Pro 64-Bit,
b. Notepad++v7.3.2 (32-Bit),
c. XAMPP version 1.8.3,
d. Apache version 2.4.7
e. PHP version 5.5.6

Perangkat lunak yang dipergunkan dalam penelitian

\section{B. Analisa Kebutuhan Perangkat Keras}

Perangkat keras yang dipergunkan dalam penelitian ini adalah Laptop Asus dengan spesifikasi sebagai berikut :

a. Processor Intel Core i5-62000U,

b. RAM 4.00 GB,

c. Harddisk 500GB

\subsection{Rancangan Basis Data}

A. ERD (Entity Relationalship Diagram)

ERD yang dirancang untuk menggambarkan atau membuat model suatu database dengan diagram yang sederhana, sehingga memudahkan dalam membuat database yang kompleks atau yang sederhana.

B. Spesifikasi Tabel

Spesifikasi tabel merupakan struktu-struktur table yang digunakan dalam perancangan berbasis data. Terdapat tujuh spesifikasi tabel berbasis data, yaitu :

Tabel 1 Spesifikasi User

\begin{tabular}{|l|l|l|l|}
\hline Nama Field & Type & Null & Key \\
\hline usemame & $\operatorname{Varchar}(50)$ & Tidak & Primary \\
\hline Password & $\operatorname{Varchar(50)}$ & Tidak & \\
\hline
\end{tabular}

C. Tabel Buku Kas Umum

Tabel 2 Spesifikasi Tabel Buku Kas Umum

\begin{tabular}{llll}
\hline Nama Field & Type & Null & Key \\
\hline id_kas & Int (10) & Tidak & Primary \\
Tanggal & Date & Tidak & \\
Uraian & Varchar (200) & Tidak & \\
Debet & Varchar (50) & Tidak & \\
Kredit & Varchar (50) & Tidak & \\
Tipe & Varchar (25) & Masuk/Keluar & \\
\hline
\end{tabular}

D. Tabel Buku Pembantu Kas

Tabel 3 Spesifikasi Tabel Buku Pembantu Kas

\begin{tabular}{lllc}
\hline Nama Field & \multicolumn{1}{c}{ Type } & \multicolumn{1}{c}{ Null } & Key \\
\hline id_kas & Int (10) & Tidak & Primary \\
Tanggal & Date & Tidak & \\
Uraian & Varchar (200) & Tidak & \\
Debet & Varchar (50) & Tidak & \\
Kredit & Varchar (50) & Tidak & \\
Tipe & Varchar (25) & Masuk/Keluar & \\
\hline
\end{tabular}

E. Tabel Buku Pembantu Bank

Tabel 4 Spesifikasi Tabel Buku Pembantu Bank

\begin{tabular}{llll}
\hline Nama Field & Type & Null & Key \\
\hline id_kas & Int (10) & Tidak & Primary \\
Tanggal & Date & Tidak & \\
Uraian & Varchar (200) & Tidak & \\
Debet & Varchar (50) & Tidak & \\
Kredit & Varchar (50) & Tidak & \\
Tipe & Varchar (25) & Masuk/Keluar & \\
\hline
\end{tabular}

F. Tabel Buku Pembantu Pajak

Tabel 5 Spesifikasi Tabel Buku Pembantu Pajak

\begin{tabular}{llll}
\hline Nama Field & Type & Null & Key \\
\hline id_kas & Int (10) & Tidak & Primary \\
Tanggal & Date & Tidak & \\
Uraian & Varchar (200) & Tidak & \\
Debet & Varchar (50) & Tidak & \\
Kredit & Varchar (50) & Tidak & \\
Tipe & Varchar (25) & Masuk/Keluar & \\
\hline
\end{tabular}


G. Tabel Data Sekolah

Tabel 6 Spesifikasi Tabel Data Sekolah

\begin{tabular}{llll}
\hline Nama Field & Type & Null & Key \\
\hline nama_sekolah & Varchar (100) & Tidak & Primary \\
Kelurahan & Varchar $(100)$ & Tidak & \\
Kecamatan & Varchar (100) & Tidak & \\
Kota & Varchar (100) & Tidak & \\
Provinsi & Varchar (100) & Tidak & \\
\hline
\end{tabular}

H. Tabel Data Pejabat

Tabel 7 Spesifikasi Tabel Data Pejabat

\begin{tabular}{llll}
\hline Nama Field & Type & Null & Key \\
\hline nama_jab1 & $\operatorname{Varchar}(100)$ & Tidak & Primary \\
nama_pejabat1 & $\operatorname{Varchar}(100)$ & Tidak & \\
nip_pejabat1 & $\operatorname{Varchar}(100)$ & Tidak & \\
nama_jab2 & $\operatorname{Varchar}(100)$ & Tidak & \\
nama_pejabat2 & $\operatorname{Varchar}(100)$ & Tidak & \\
nip_pejabat2 & $\operatorname{Varchar}(100)$ & Tidak & \\
\hline
\end{tabular}

4.4 Rancangan Antarmuka Aplikasi

Tampilan Antarmuka Halaman Login

** LAPORAN DANA BOS ** Sliakan bogin teribin dahulu

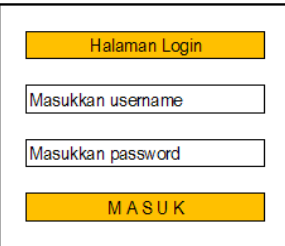

Gambar 3. Antarmuka Halaman Login

Tampilan Antarmuka Halaman Utama

"LAPORAN DANA BOS ** OHome OData Master OLaporan Kevengan GProfil

\section{Sistem Informasi Pelaporan Dana BOS \\ SMK NEGERI 2 PONTIANAK \\ Gambar 4. Antarmuka Halaman Utama}

Tampilan Antarmuka Data Master

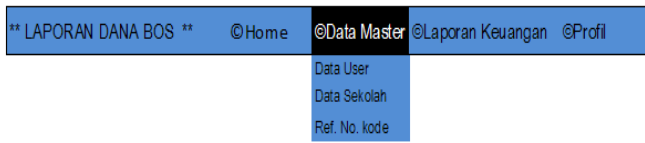

\section{Sistem Informasi Pelaporan Dana BOS SMK NEGERI 2 PONTIANAK}

Gambar 5. Antarmuka Menu Data Master

Tampilan Antarmuka Laporan Keuangan

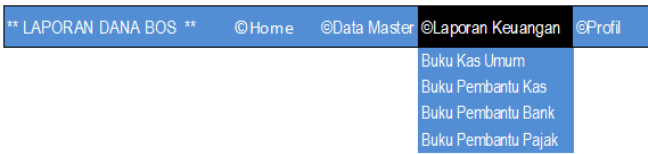

\section{Sistem Informasi Pelaporan Dana BOS} SMK NEGERI 2 PONTIANAK

Gambar 6. Antarmuka Halaman Laporan Keuangan
Tampilan Antarmuka Menu Buku Kas Umum

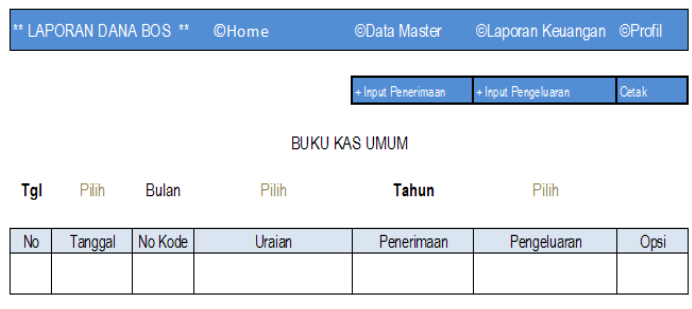

Gambar 7. Antarmuka Menu Buku Kas Umum

Tampilan Antarmuka Menu Buku Pembantu Kas

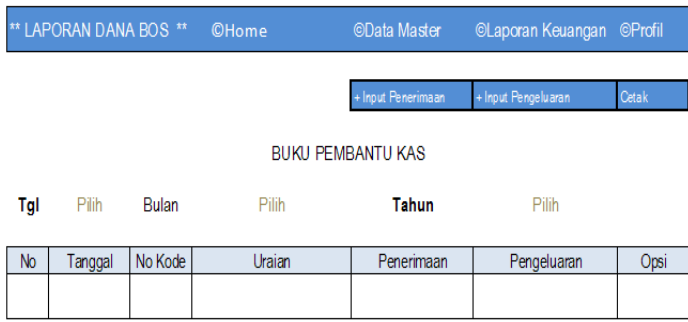

Gambar 8 Antarmuka Menu Buku pembantu Kas

Tampilan Antarmuka Menu Buku Pembantu Bank

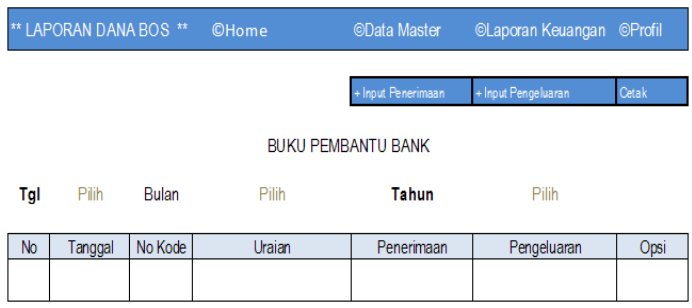

Gambar 9 Antarmuka Menu Buku pembantu Bank

Tampilan Antarmuka Menu Buku Pembantu Pajak " LAPORAN DANABOS * OHome OData Master Olaporan Keuangan OProfil

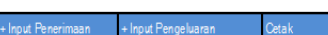

BUKU PEMBANTU PA.JAK

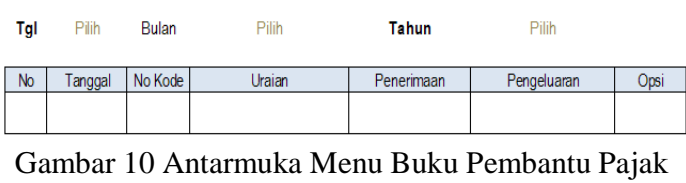

Tampilan Antarmuka Menu Input Data Penerimaan
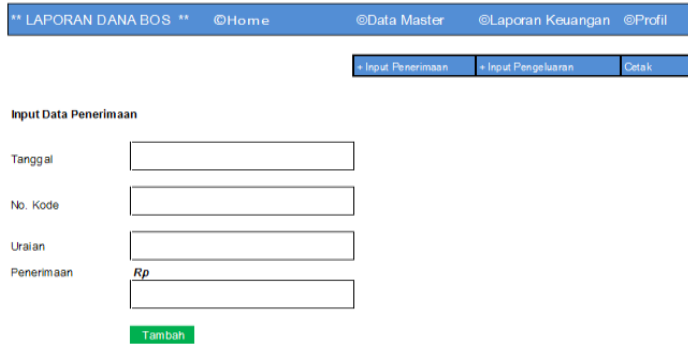

Gambar 11 Antarmuka Menu Input Data Penerimaan 
Tampilan Antarmuka Menu Input Data Pengeluaran

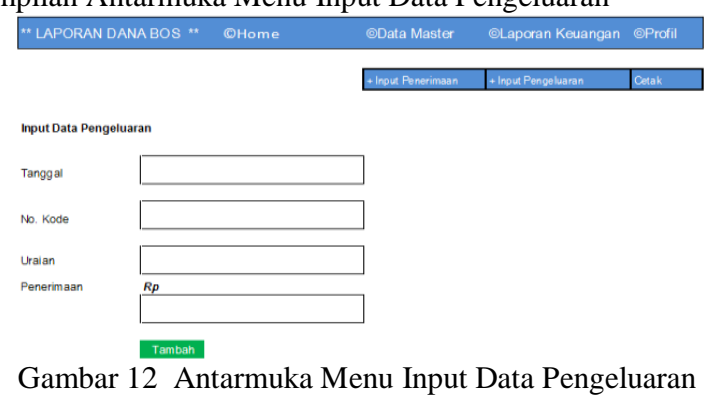

\subsection{Hasil Analisa}

Hasil Analisa aplikasi pelaporan dana Bantuan Operasional Sekolah (BOS) sudah selesai dibuat dan dapat diimplementasikan di SMK Negeri 2 Pontianak. Implementasi pada aplikasi ini dapat dilakukan dengan melihat spesifikasi kebutuhan aplikasi dan member petunjuk cara mengakses aplikasi, sehingga memudahkan pihak yang menggunakan aplikasi ini dalam mengimplementasikannya.

\section{Proses Akses Aplikasi}

Proses akses pada aplikasi dapat dilakukan berbagai platform, seperti laptop, smartphone atau tablet. Proses ini dilakukan dengan mengkoneksikan wifi SMK Negeri 2 Pontianak dengan alamat http://bos.gis.my.id/

\section{Tampilan Halaman Login}

Halaman login digunakan untuk dapat menampilkan halaman utama pada aplikasi ini. Untuk dapat menggunakan semua fitur bendahara harus melakukan proses login terlebih dahulu. Adapun tampilan halaman login dapat dilihat pada Gambar 13

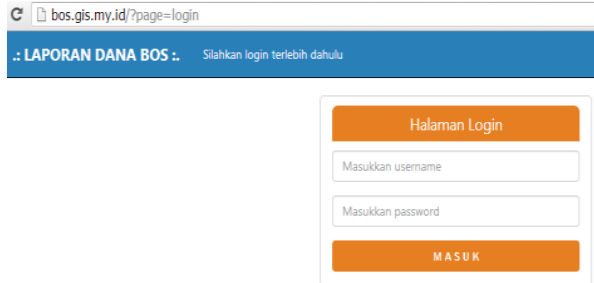

Gambar 13 Tampilan Halaman Login

Pada halaman ini Bendahara / Kepsek harus login terlebih dahulu dengan memasukkan username dan password yang sudah diberikan, dan setelah itu baru dapat menggunakan semua fitur yang ada pada Aplikasi pelaporan dana Bantuan Operasioanal Sekolah (BOS)

\section{a. Tampilan Halaman Utama}

Tampilan halaman utama Aplikasi Pelaporan Dana Bantuan Operasional Sekolah (BOS) SMK Negeri 2 Pontianak seperti tampak pada Gambar 14

\section{Sistem Informasi Pelaporan Dana BoS SMK NEGERI 2 PONTIANAK}

Gambar 14 Tampilan Halaman Utama

Setelah masuk kehalaman utama Bendahara/Kepsek dapat masuk ke menu Data Master, menu Laporan Keuangan dan menu Profil.

\section{b. Tampilan Halaman Data Master}

Tampilan Halaman Data Master berisi tentang Data User, Data Sekolah dan Referinsi No. Kode seperti tampak pada Gambar 15

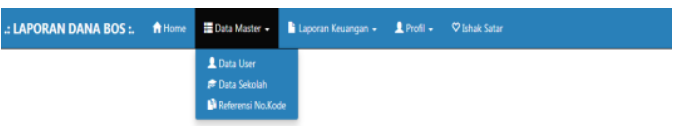

\section{Sistem Informasi Pelaporan Dana BOS SMK NEGERI 2 PONTIANAK}

Gambar 15 Tampilan Halaman Data Master

Pada data master terdapat tiga dipilihan menu, yaitu :

1. Data User bersikan kode user, username, nama lengkap, jenis kelamin, no telpon, alamat, level dan opsi.

2. Data Sekolah berisikan Nama Sekolah, Kelurahan, Kecamatan, Kabupaten/Kota, Provinsi dan Nama Pejabat (opsi).

3. Referensi No Kode berisikan no kode akun yang dapat ditambah atau dikurangi sesuai kebutuhan bendahara.

Tampilan Data User dapat dilihat seperti pada Gambar 16
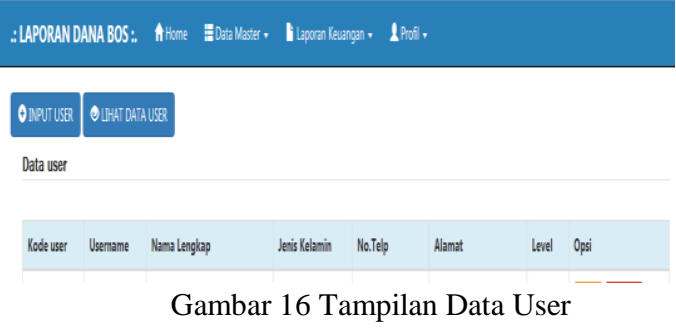

Data Sekolah dapat dilihat Gambar 17

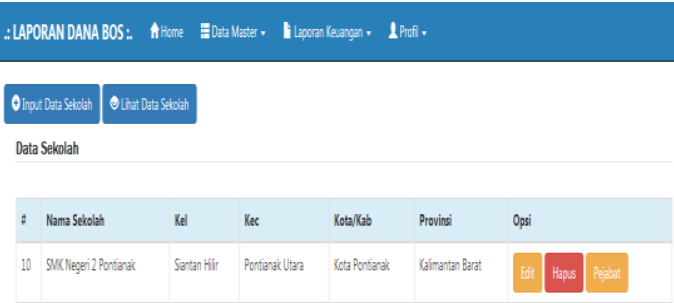

Gambar 17 Tampilan Data Sekolah

\section{Tampilan Halaman Laporan Keuangan}

Tampilan Halaman Laporan Keuangan berisi tentang Buku Kas Umum, Buku Pembantu Kas, Buku Pembantu Bank dan Buku Pembantu Pajak seperti pada gambar 18

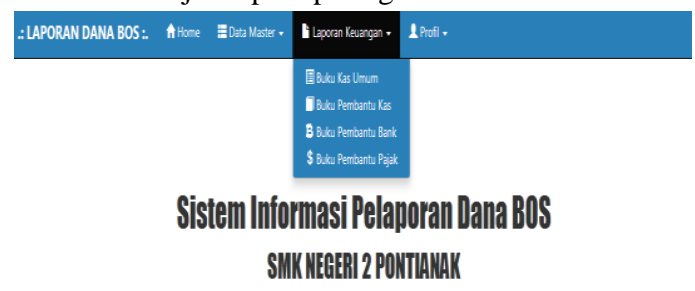

Gambar 18 Tampilan Halaman Laporan Keuangan Jika kita memilih Buku Kas Umum maka tampilan menu pada Buku Kas Umum dapat dilihat seperti gambar 19 


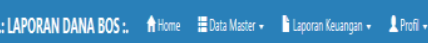

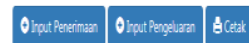

BUKU KAS UMUM

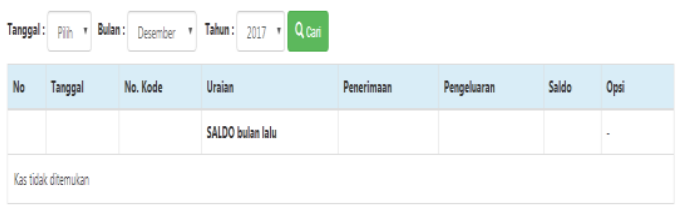

Gambar 19 Tampilan Buku Kas Umum

Pada Buku Kas Umum Bendahara dapat memilih Input Penerimaan jika ingin memasukkan transaksi penerimaan dan Iput Pengeluaran jika bendahara ingin mengentry transaksi pengaluaran. Tampilan Buku Pembantu Kas dapat dilihat seperti gambar 20

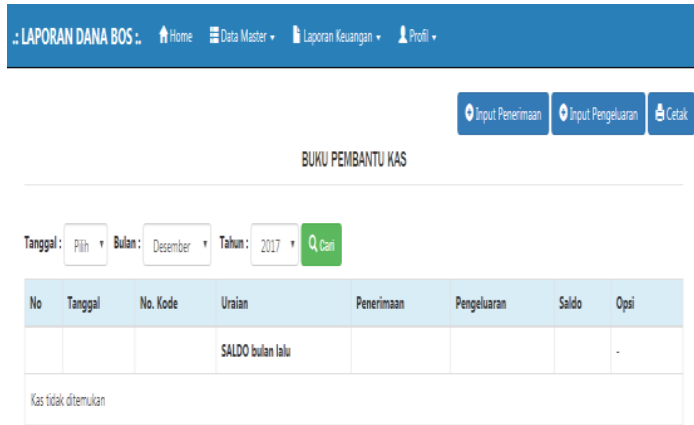

Gambar 20. Tampilan Buku Pembantu Kas

Pada Buku Pembantu Kas Bendahara dapat memilih Input Penerimaan jika ingin memasukkan transaksi penerimaan Buku Pembantu Kas dan Iput Pengeluaran jika bendahara ingin mengentry transaksi pengaluaran Buku Pembantu Kas.

Tampilan Buku Pembantu Bank dapat dilihat seperti gambar 21
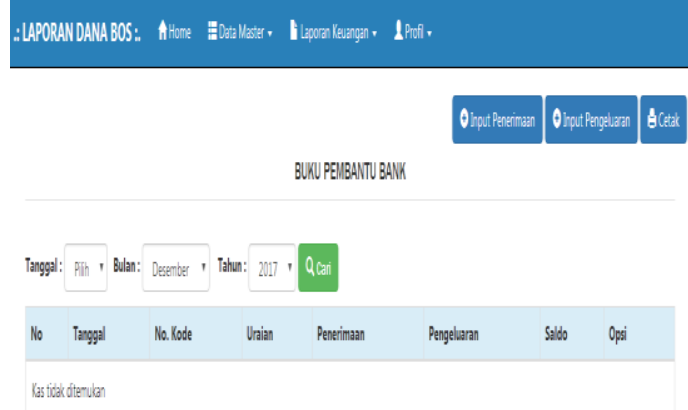

Gambar 21 Tampilan Buku Pembantu Bank

Pada Buku Pembantu Bank Bendahara dapat memilih Input Penerimaan jika ingin memasukkan transaksi penerimaan Buku Pembantu Bank dan Iput Pengeluaran jika bendahara ingin mengentry transaksi pengaluaran Buku Pembantu Bank Tampilan Buku Pembantu Pajak dapat dilihat seperti gambar 21

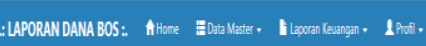

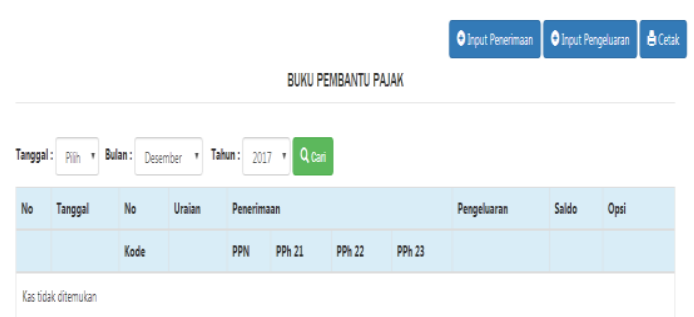

Gambar 21 Tampilan Buku Pembantu Pajak

Pada Buku Pembantu Pajak Bendahara dapat memilih Input Penerimaan jika ingin memasukkan transaksi penerimaan Buku Pembantu Pajak dan Iput Pengeluaran jika bendahara ingin mengentry transaksi pengaluaran Buku Pembantu Pajak. Tampilan Input Data Penerimaan semua transaksi pada BKU, BPK, BPB dan BPP adalah sama seperti seperti gambar 22

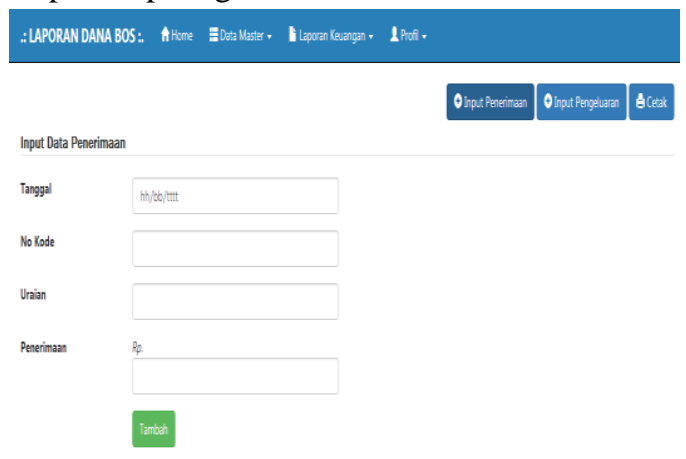

Gambar 22 Tampilan Tampilan Input Data Penerimaan

Pada Gambar 23 Bendahara pertama mengisi data tanggal, no kode transaksi, uraian transaksi dan nilai transaksi penerimaan. Jka semua sudah terisi baru pilih menu Tambah, maka proses input data penerimaan telah selesai dilakukakan dan data tersebut tersimpan diaplikasi. Tampilan Input Data Pengeluaran semua transaksi pada BKU, BPK, BPB dan BPP adalah sama seperti seperti gambar 23

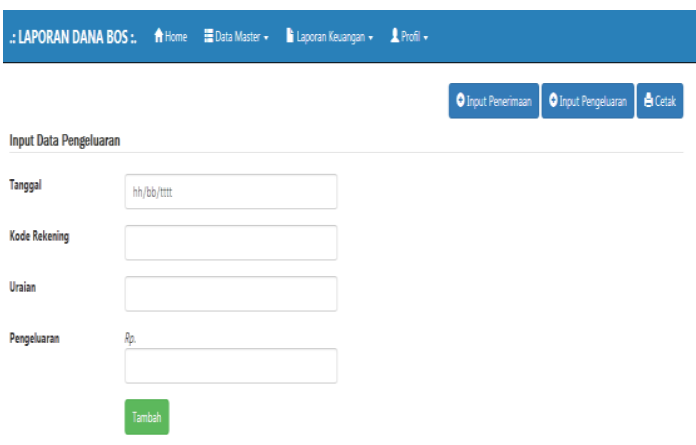

Gambar 23 Tampilan Tampilan Input Data Pengeluaran Pada Gambar 23 Bendahara pertama mengisi data tanggal, no kode transaksi, uraian transaksi dan nilai transaksi penerimaan. Jka semua sudah terisi baru pilih menu Tambah, maka proses input data pengeluaran telah selesai dilakukakan dan data tersebut tersimpan diaplikasi. 
4.6. Hasil Cetakan Aplikasi Pelaporan Dana BOS

1. Buku Kas Umum

Hasil Cetakan Buku Kas Umum seperti gambar 24

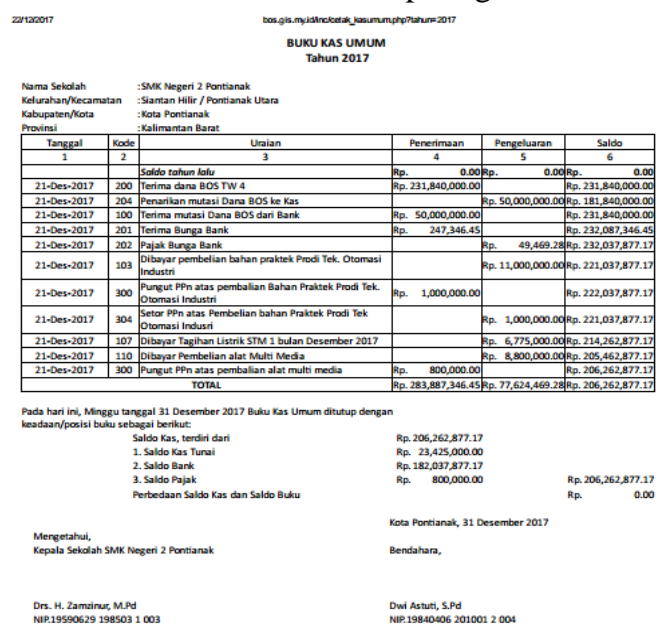

Gambar 24 Hasil Cetakan Buku Kas Umum

2. Buku Pembantu Kas

Hasil Cetakan Buku Pembantu Kas seperti gambar 25

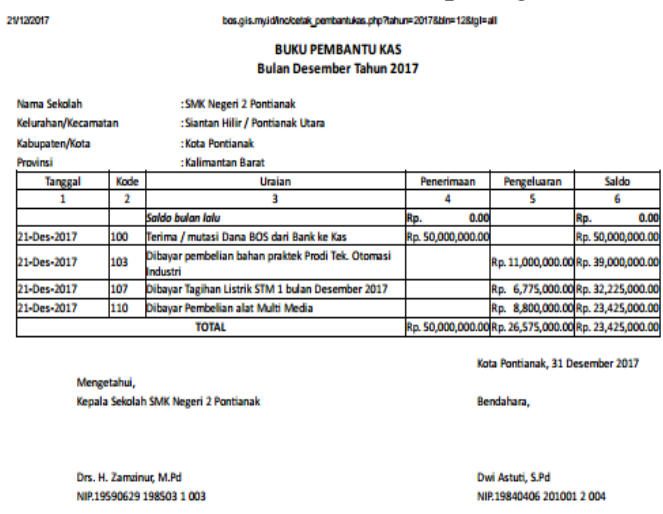

Gambar 25 Hasil Cetakan Buku Pembantu Kas

3. Buku Pembantu Bank

Hasil Cetakan Buku Pembantu Bank seperti gambar 26

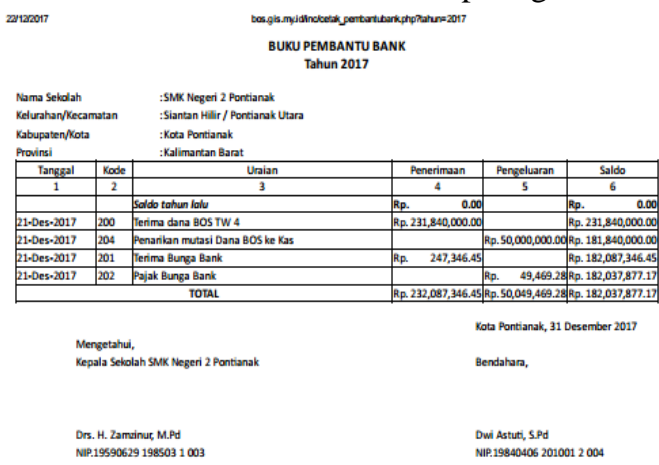

Gambar 26 Hasil Cetakan Buku Pembantu Bank

4. Buku Pembantu Pajak

Hasil Cetakan Buku Pembantu Pajak seperti gambar 27

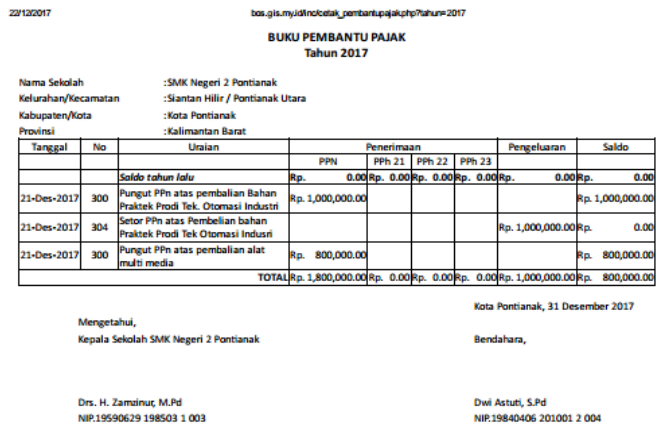

Gambar 27 Hasil Cetakan Buku Pembantu Pajak

\section{a. Pengujian Black Box}

Metode pengujian Black Box ini merupakan pengujian yang berfokus pada spesifikasi fungsional dari perangkat lunak, tester dapat mendefinisikan kumpulan kondisi input dan melakukan pengujian untuk menemukan kesalahan pada aplikasi. Pada pengujian ini menggunakan pengujian black box dengan parameter data kosong.

\begin{tabular}{|c|c|c|c|c|}
\hline Menu & Kondisi & Password & $\begin{array}{c}\text { Hasil } \\
\text { Eksekusi }\end{array}$ & Keterangan \\
\hline Login & Data & & Tidak & Tidak berhasil login dan \\
\hline Admin & Kosong & & $\begin{array}{l}\text { Berhasil } \\
\text { Login }\end{array}$ & $\begin{array}{l}\text { sistem meunculkan alert } \\
\text { (lihat gambar } 4.16 \text { ) }\end{array}$ \\
\hline Login & Data & AdminN & Tidak & Tidak berhasil login dan \\
\hline Admin & Salah & & $\begin{array}{l}\text { Berhasil } \\
\text { Login }\end{array}$ & $\begin{array}{l}\text { sistem meunculkan alert } \\
\text { (lihat gambar } 4.17 \text { ) }\end{array}$ \\
\hline $\begin{array}{l}\text { Login } \\
\text { Admin }\end{array}$ & $\begin{array}{l}\text { Data } \\
\text { benar }\end{array}$ & admin & $\begin{array}{l}\text { Berhasil } \\
\text { Login }\end{array}$ & $\begin{array}{l}\text { Berhasil login dan akan } \\
\text { masuk ke halaman utama } \\
\text { (lihat gambar } 4.18 \text { ) }\end{array}$ \\
\hline
\end{tabular}

Hasil eksekusi password kosong dapat dilihat pada

Gambar 28 dibawah ini :

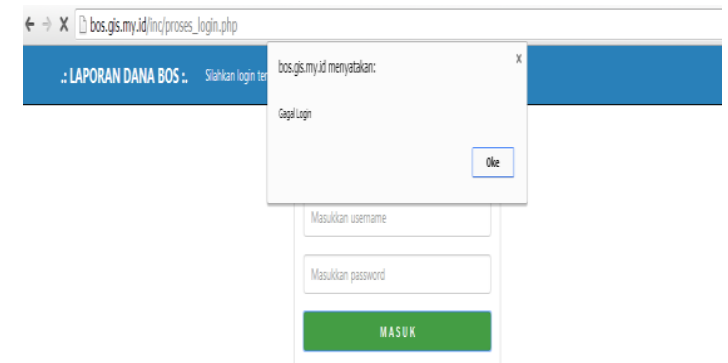

Gambar 28 Alert password kosong

Hasil eksekusi password salah dapat dilihat pada Gambar 29 dibawah ini :

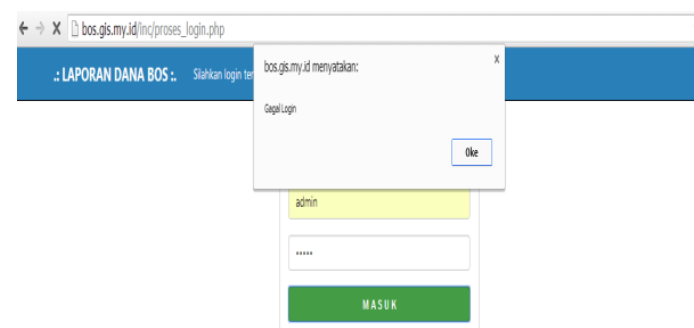

Gambar 29 Alert password salah

Hasil eksekusi password benar dapat dilihat pada Gambar 30 dibawah ini : 


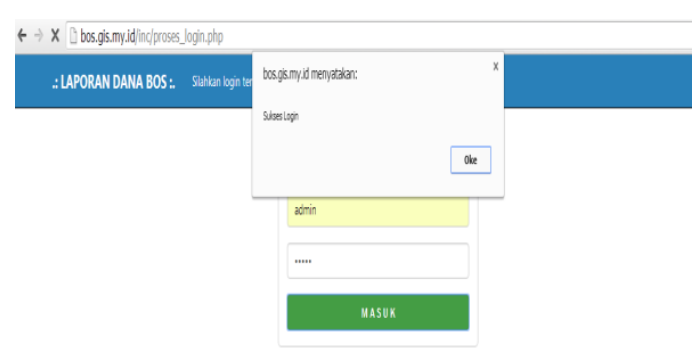

Gambar 30 Alert password benar

Tabel 9 Tabel Hasil Pengujian Black Box Input Data

\begin{tabular}{|c|c|c|c|c|}
\hline \multicolumn{5}{|c|}{ Penerimaan } \\
\hline Menu & Kondisi & $\begin{array}{c}\text { Peneri } \\
\text { maan }\end{array}$ & $\begin{array}{c}\text { Hasil } \\
\text { Eksekusi }\end{array}$ & Keterangan \\
\hline $\begin{array}{l}\text { Input } \\
\text { Data } \\
\text { Penerim } \\
\text { aan }\end{array}$ & $\begin{array}{l}\text { Data } \\
\text { Salah }\end{array}$ & $267 a$ & $\begin{array}{l}\text { Tidak } \\
\text { Berhasil } \\
\text { tambah } \\
\text { transaksi }\end{array}$ & $\begin{array}{l}\text { Tidak berhasil } \\
\text { tambah transaksi } \\
\text { dan sistem } \\
\text { memunculkan fiture } \\
\text { (lihat gambar 4.18) }\end{array}$ \\
\hline $\begin{array}{l}\text { Input } \\
\text { Data } \\
\text { Penerim } \\
\text { aan }\end{array}$ & $\begin{array}{l}\text { Data } \\
\text { benar }\end{array}$ & $\begin{array}{l}26700 \\
0000\end{array}$ & $\begin{array}{l}\text { Berhasil } \\
\text { tambah } \\
\text { transaksi }\end{array}$ & $\begin{array}{l}\text { Berhasil tambah } \\
\text { transaksi dan sistem } \\
\text { memunculkan fiture } \\
\text { (lihat gambar 4.19) }\end{array}$ \\
\hline
\end{tabular}

Hasil eksekusi input data penerimaan salah dapat dilihat pada gambar 31

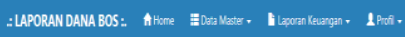

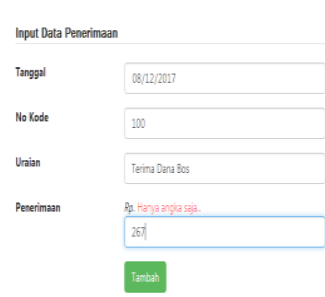

Gambar 31 Alert input data penerimaan salah

Hasil eksekusi input data penerimaan benar dapat dilihat pada gambar 32

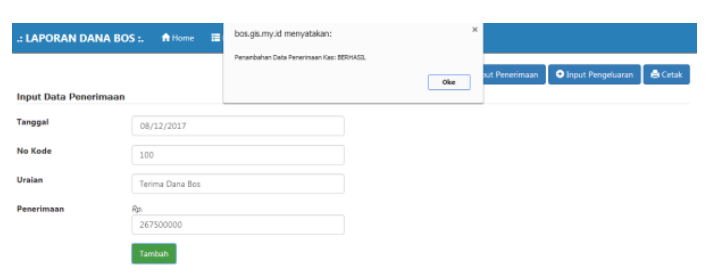

Gambar 32 Alert input data penerimaan benar

Hasil entri input data penerimaan benar akan tampak hasilnya seperti pada gambar 33

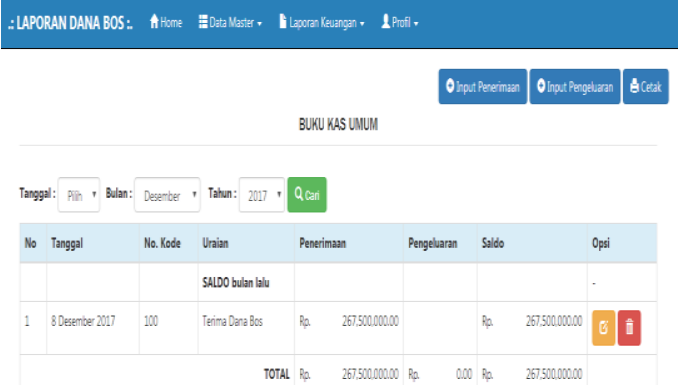

Gambar 33 Input Data Penerimaan Berhasil

Tabel 10 Tabel Hasil Pengujian Black Box Input Data

\begin{tabular}{|c|c|c|c|c|}
\hline \multicolumn{5}{|c|}{ Pengeluaran } \\
\hline Menu & Kondisi & $\begin{array}{c}\text { Penerin } \\
\text { an }\end{array}$ & $\begin{array}{c}\text { Hasil } \\
\text { Eksekusi }\end{array}$ & Keterangan \\
\hline $\begin{array}{l}\text { Input } \\
\text { Data } \\
\text { Pengelu } \\
\text { aran }\end{array}$ & $\begin{array}{l}\text { Data } \\
\text { Salah }\end{array}$ & $3775 p$ & $\begin{array}{l}\text { Tidak } \\
\text { Berhasil } \\
\text { tambah } \\
\text { transaksi }\end{array}$ & $\begin{array}{l}\text { Tidak berhasil } \\
\text { tambah transaksi } \\
\text { dan sistem } \\
\text { memunculkan fiture } \\
\text { (lihat gambar 4.18) }\end{array}$ \\
\hline $\begin{array}{l}\text { Input } \\
\text { Data } \\
\text { Pengelu } \\
\text { aran }\end{array}$ & $\begin{array}{l}\text { Data } \\
\text { benar }\end{array}$ & 377500( & $\begin{array}{l}\text { Berhasil } \\
\text { tambah } \\
\text { transaksi }\end{array}$ & $\begin{array}{l}\text { Berhasil tambah } \\
\text { transaksi dan sistem } \\
\text { memunculkan fiture } \\
\text { (lihat gambar 4.19) }\end{array}$ \\
\hline
\end{tabular}

Hasil eksekusi input data pengeluaran salah dapat dilihat pada gambar 34

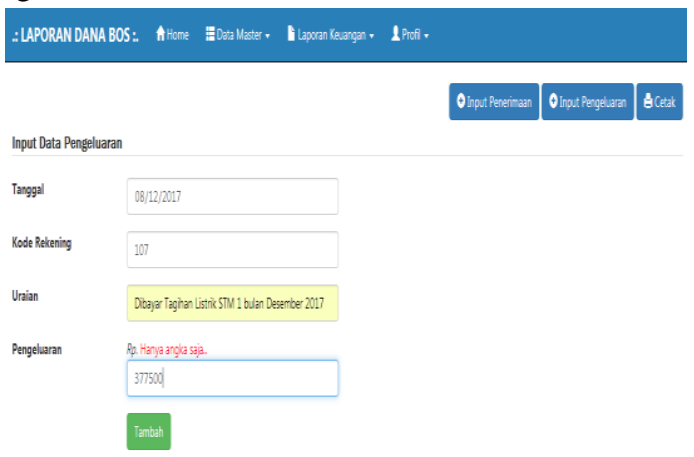

Gambar 34 Alert input data pengeluaran salah

Hasil eksekusi input data pengeluaran benar dapat dilihat pada gambar 34

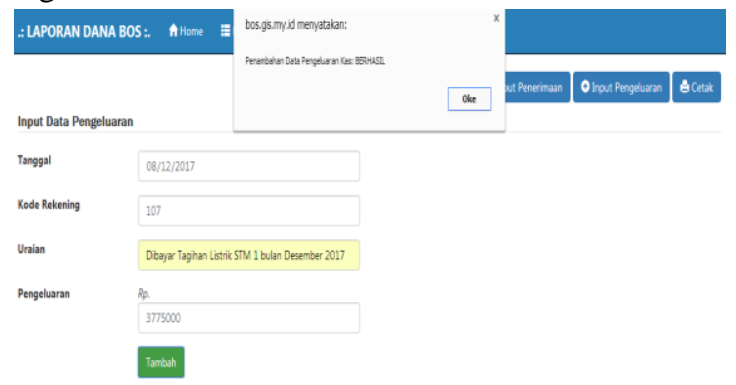

Gambar 35 Alert input data pengeluaran benar Hasil entri input data pengeluaran benar akan tampak hasilnya seperti pada gambar 36 


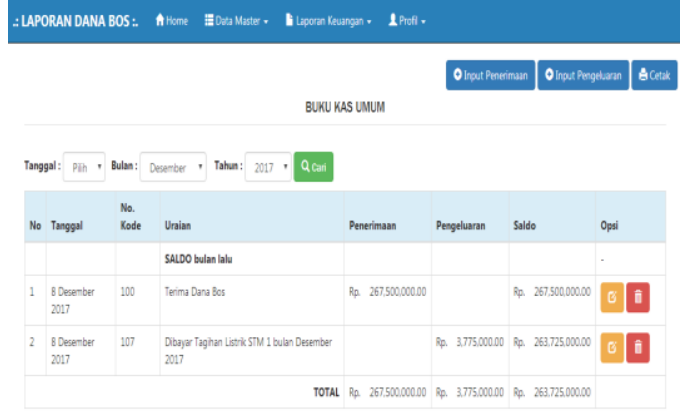

Gambar 36 input data pengeluaran berhasil

\subsection{Analisis Hasil Pengujian Black Box}

Analisis hasil pengujian Black Box bertujuan mengetahui keberhasilan dari input. Pada Pengujian ini terdapat beberapa hasil pengujian sebagai berikut :

$>$ Pengujian Black Box dengan password

Hasil pengujian yang tidak berhasil login jika dalam kondisi data kosong, data salah atau salah menggunakan huruf kapital, sehingga sistem akan menampilkan alert pada aplikasi yaitu gagal login.

Bendahara dapat berhasil login apabila memasukkan data password dengan benar dan sistem akan menyampaikan alert pada aplikasi yaitu sukses login.

$>$ Pengujian Black Box Input Data Penerimaan

Hasil pengujian Black Box Input Data Penerimaan yang tidak berhasil dientri data keuangan jika menggunkan huruf, sehingga sistem akan menampilkan fiture pada aplikasi yaitu hanya angka saja.

Jika entri data peneriamaan diisi dengan nominal angka maka sistem akan menyampaikan pada aplikasi yaitu

\section{Penambahan Data Penerimaan Kas BERHASIL.}

$>$ Pengujian Black Box Input Data Pengeluaran

Hasil pengujian Black Box Input Data Pengeluaran yang tidak berhasil dientri data keuangan jika menggunkan huruf, sehingga sistem akan menampilkan fiture pada aplikasi yaitu hanya angka saja.

Jika entri data pengeluaran diisi dengan angka maka sistem akan menyampaikan pada aplikasi yaitu Penambahan

\section{Data Pengeluaran Kas BERHASIL.}

\section{Analisis Sisi Pengguna}

Sesuai analisis kebutuhan pengguna, penulis telah mewawancarai pengguna dalam hal ini bendahara SMK Negeri 2 Pontianak dan menguji aplikasi ini secara langsung untuk mengetahui efektifitas aplikasi dana BOS ini. Hasilnya terdapat beberapa point sebagai berikut :

\section{$>$ Dari segi Efektifitas}

Diketahui bahwa informasi yang tersedia dari aplikasi ini sudah sesuai kebutuhan baik dari sisi akurasi (mengurangi tingkat kesalahan input data di buku dan direkap/laporan), ketersediaan (kelengkapan) data dan perlindungan data (dengan adanya pin yang hanya diketahui oleh orang tertentu yaitu Bendahara, Kepala Sekolah dan Diknasbud).

Selain itu format dan data yang tersedia sudah sesuai format dari Diknasbud Kalbar untuk pelaporan dana BOS.

$>$ Dari segi Efisiensi

Diketahui bahwa informasi yang tersedia dari aplikasi ini sudah bisa menghemat jumlah tenaga pengguna, menghemat jenis pekerjaan serta biaya khususnya pembelian buku, tinta dan pen untuk kegiatan pelaporan karena cukup sekali entry data bisa langsung menghasilkan laporan keuangan dan pencatatan dibuku kas umum, kas pembantu, buku pembantu bank dan pajak.

\section{Kesimpulan}

Berdasarkan hasil Analisis Aplikasi Pelaporan Dana Bantuan Operasional Sekolah (BOS), dapat disimpulkan sebagai berikut :

1. Aplikasi pelaporan dana Bantuan Operasional Sekolah (BOS) ini dibuat dengan melalui proses analisis kebutuhan, proses perancangan aplikasi dan proses pembuatan aplikasi hingga didapatkan hasil yang diinginkan.

2. Hasil pengujian aplikasi pelaporan dana Bantuan Operasional Sekolah dilakukan melalui pengujian black box dan hasilnya telah berjalan sesuai dengan fungsinya.

3. Aplikasi ini sangat membantu manajemen SMK Negeri 2 Pontianak dalam Pelaporan Penggunaan Dana Bantuan Sekolah (BOS) sebagai laporan ke Dinas Pendidikan dan Kebudayaan Provinsi Kalimantan Barat.

\section{Referensi}

[1.] Arief, M. Rudianto. 2011. Pemograman Web menggunkan Dinamis Menggunakan PHP dan MySQL. Andi Publisher. Jakarta.

[2.] Ariestyo, Rio Ridha. 2013. Sistem Informasi Pengelolaan Dana Bantuan Operasional Sekolah (BOS) di SMP Surabaya. Politeknik Elektronika ITS. Surabaya. Tersedia : https://www.pens.ac.id/uploadta/downloadmk.php?id=179 2 [2 Oktober 2017]

[3.] Direktorat Pembinaan SMK. Dirjen Pedidikan Dasar dan Menegah Kementerian Pendidikan dan Kebudayaan. 2016. Panduan Sukses Bendahara BOS SMK. Jakarta.

[4.] Dirjen Pedidikan Dasar dan Menegah Kementerian Pendidikan dan Kebudayaan, 2016. Petunjuk Teknis Penggunaan dan Petanggungjawaban Keuangan Dana Bantuan Oprasional Sekolah untuk SMK. Jakarta

[5.] Kadir, Abdul. 2005. Dasar Pemrograman Web Dengan $A S P$. Andi. Yogyakarta.

[6.] Kustiyahningsih, Y \& Anamisa, Devie R. 2011. Pemrograman Basis Data. Berbasis Web Menggunakan $P H P \& M y S q l$. Graha Ilmu. MADCOMS. Yogyakarta

[7.] Notoatmodjo, S. 2012. Metodologi Penelitian. Rineka Cipta. Jakarta

[8.] Nuranto, Ardia. 2014 Sistem Informasi Pelaporan Dana Bantuan BOS SD Negeri 006 Tanjung Pinang Timur. STTI Tanjungpinang. 